\title{
Construction and characterization of a genomic library of Colletotrichum horii from persimmon
}

\author{
Sun $\mathrm{H}^{1,2}$, Zhang $\mathrm{JZ}^{1}$, Zhang $\mathrm{LL}^{1}$ and Hyde $\mathrm{KD}^{3,4}$ \\ ${ }^{1}$ Key Laboratory of Molecular Biology of Crop Pathogens and Insects, Ministry of Agriculture, Institute of \\ Biotechnology, College of Agricultural \& Biotechnology, Zhejiang University, Kaixuan road 258, Hangzhou 310029 \\ ${ }^{2}$ Institute of Plant Protection, Henan Academy of Agricultural Sciences, Zhengzhou 450002 \\ ${ }^{3}$ School of Science, Mae Fah Luang University, Chiang Rai, Thailand \\ ${ }^{4}$ King Saud University, College of Science, Botany and Microbiology Department, P.O. Box: 2455, Riyadh 1145, Saudi \\ Arabia
}

Sun H, Zhang JZ, Zhang LL, Hyde KD 2012 - Construction and characterization of a genomic library of Colletotrichum horii from persimmon. Plant Pathology \& Quarantine 2(1), 1-8, doi $10.5943 / \mathrm{ppq} / 2 / 1 / 1 /$

A cosmid library from genomic DNA of Colletotrichum horii, the fungal pathogen causing persimmon anthracnose is constructed. We established a extraction method for obtaining 145-250 $\mathrm{kb}$ genomic DNA, which is suitable for a cosmid library construction. The cloning procedures were as follows: mycelia was obtained following conidial germination, smaller fragments were removed from purified DNA through capillary ligation of the DNA to the cosmid vector, and in vitro packaging into the lambda phage. The library presently consists of $4.78 \times 10^{4}$ independent clones with an average insert size of about $34 \mathrm{~kb}$. This cosmid library is the first to be constructed for cloning the pathogenesis related genes of $C$. horii and for analyzing the molecular and genetic characteristics of this species.

Keywords - anthracnose - DNA purification - genomic DNA - pathogenesis

\section{Article Information}

Received 11 January 2012

Accepted 11 January 2012

Published online 21 February 2012

*Corresponding author: Zhang JZ - e-mail - jzzhang@zju.edu.cn

\section{Introduction}

Anthracnose of persimmon is a destructive disease (Zhang 2008, Xie et al. 2010) The disease is severe in persimmon nurseries and in orchards, causing serious economic losses to growers and has become a central problem in the development of persimmon industry in China (Zhang 2008, Xie et al. 2010). The pathogen causing this disease was identified previously as Colletotrichum gloeosporioides (Penz.) Penz. \& Sacc. (Zhang et al. 2005b) and subsequently named $C$. horii ( Hyde et al. 2009, Weir \& Johnston). Intra-cellular infection structures revealed during the infection processes have shown that $C$. horii is a hemibiotrophic species on Persimmon. Duri- ng the biotrophic stage in persimmon, C. horii infection vesicles and primary hyphae are surrounded by an interfacial matrix that separates the fungal cell wall from the invaginated host plasma membrane, closely resembling that of $C$. lindemuthianum on bean (Zhang et al 2003, Zhang et al 2005a, Zhang 2008, Xie et al. 2010). C. horii provides an excellent pathosystem for studying the molecular basis for infection structure differentiation and fungal-plant interactions. However, the mole-cular mechanisms of interactions between the pathogen and host have not been investigated.

To understand fungus-host interactions, mutants related to pathogenesis-related genes 
were obtained by Agrobacterium tumefaciensmediated transformation and their fragments relating to pathogenesis-related genes were cloned (Sun et al 2008). For genes isolation and structure analysis it is important to construct a cosmid library. Here we report on a genomic library constructed for $C$. horii isolate TSG001 using SuperCos1 Cosmid Vector and its molecular characterization.

\section{Material and Methods}

Fungal material and culture

Colletotrichum horii isolate TSG001 in this study was isolated previously from Diospyros kaki cv. Wuheshi in Chunan area, Zhejiang province, China (Zhang et al 2005b). It was routinely stored with mycelial plugs $(5 \mathrm{~mm})$ [glycerol-water, $20 \%$ (vol/vol)] at $-70^{\circ} \mathrm{C}$.

Plugs were removed from cryotubes and transferred to Petri dishes containing potato dextrose agar (PDA). Colonies were grown at $25^{\circ} \mathrm{C}$ under a near UV light with a $12 \mathrm{~h}$ photoperiod. Conidia were collected from cultures from 8 day-old cultures and washed twice with sterile water, and resuspended to $1 \times 10^{6}$ conidia $/ \mathrm{mL}$ in sterile water. A $50 \mu \mathrm{L}$ aliquot of conidial suspension was dropped into a flask containing $300 \mathrm{~mL}$ PDB (potato dextrose broth) and fungal mycelia were produced by shaking $\left(180 \mathrm{r} / \mathrm{min}\right.$ for $48 \mathrm{~h}$ at $\left.25^{\circ} \mathrm{C}\right)$. Mycelia were collected on sterile filter papers for subsequent DNA extraction.

\section{Preparation of high-molecular-weight DNA}

$5 \mathrm{~g}$ mycelia were submerged in liquid nitrogen and ground into a fine powder in by using a mortar. The powder was transferred into a $50 \mathrm{~mL}$ centrifuge tube and $20 \mathrm{~mL}$ of $1 \times$ TEN9 buffer(50 mmol/L Tris.CL (pH 9.0), 100 $\mathrm{mmol} / \mathrm{L}$ EDTA-Na $2,200 \mathrm{mmol} / \mathrm{L} \mathrm{NaCL}$ ) was added. After the powder was dissolved thoroughly, $200 \mu \mathrm{L}$ RNase stock $(0.1 \mu \mathrm{g} / \mu \mathrm{L})$ were added, and then $1 \mathrm{~mL}$ of $20 \%$ SDS and 1 $\mathrm{mL}$ proteinase $\mathrm{K}(10 \mathrm{mg} / \mathrm{mL})$ were added into the tube, which was incubated on a rocker platform at $37^{\circ} \mathrm{C}$ for $24 \mathrm{~h}$. To remove the proteins from the sample, phenol extraction was performed, using equal Vol. phenol: chloroform: isoamylalcohol (25:24:1). After the sample was centrifuged, supernatant was transferred into a new tube and phenol extrac- tion was repeated two times. The aqueous phase was removed into dialysis bag, which was placed into TE $(10 \mathrm{mM}$ Tris-HCL $\mathrm{pH} 8,1$ $\mathrm{mM}$ EDTA) $(1: 1000 \mathrm{v} / \mathrm{v})$ for $2 \mathrm{~h}$ at room temperature and then at $4{ }^{\circ} \mathrm{C}$ overnight. The sample was transferred into a new tube from dialysis bag, and 1/10 vol. of $3 \mathrm{M} \mathrm{NaAc}(\mathrm{pH}$ 5.2) and 1 vol. isopropanol were added. The precipitated DNA was picked out by capillary, washed twice with $70 \%$ ethanol and was resuspended in $2 \mathrm{~mL}$ TE. The quality of the genomic DNA was checked by pulse field gel electrophoresis (PFGE) in a CHEF Mapper XA system (Bio-Rad Laboratories) at $14^{\circ} \mathrm{C}$ for 18 h. Lambda ladder PFG marker (New England Biolabs, USA) was used as a molecular size marker.

\section{Insert DNA preparation}

Partial digestions of the genomic DNA were carried out with different amounts of enzyme Sau 3AI (Takara, Japan) and digestion time. The optimal conditions firstly were established for obtaining The DNA fragments of $30-42 \mathrm{~kb}$ in length, and then a large scale digestion was performed for preparing insert DNA. After digesting, the DNA fragments was extracted with phenol-chloroform, precipitated with sodium acetate and ethanol, and then dephosphorated by $5 \mu \mathrm{L}(0.5 \mathrm{U} / \mu \mathrm{L})$ CIAP (Calf intestinal alkaline phosphatase, Promega, USA) at $37^{\circ} \mathrm{C}$ for $1 \mathrm{~h}$. Subsequently, the reaction in samples were terminated by adding $1 \mu \mathrm{L}$ of 0.5 M EDTA and incubated at $68{ }^{\circ} \mathrm{C}$ for $10 \mathrm{~min}$. The samples were followed by phenol/chloroform and chloroform extraction, ethanol precipitation, and resuspension in water.

At the same time, the Super Cos1 vector used in this study was linearized by $\mathrm{XbaI}$ (Takara, Japan), dephosphorylated By CIAP (Promega), digested by BamHI (Takara, Japan) and then two DNA fragments was purified by Axyprep PCR Cleanup kit (Axygen, USA), respectively, according to the manufacturer's instructions.

\section{In vitro packaging}

The DNA fragments of $30-42 \mathrm{~kb}$ were ligated into the Super Cos1 vector by $\mathrm{T}_{4}$-DNA Ligase (Takara, Japan). The ligations were packaged in vitro into the $\lambda \mathrm{cll} 85 \mathrm{Sam} 7$ Lambda (supplied in the Gigapack XL-11 
Packaging Extract Kit) and plated with the Escherichia coli strains XL1-Blue MR onto NZY medium according to the manufacturer's instructions.

\section{Quality of the packaged cosmids}

The titer of the packaged cosmids was analyzed, adding $10 \mu \mathrm{L}$ of the packaged cosmids with a serial dilution to $100 \mu \mathrm{L}$ of he bacterial plating strain XL1-Blue MR host cells (supplied in the kit), and then the packaged cosmids were absorbed at room temperature for $30 \mathrm{~min}$. The infected bacteria were spread on LB-ampicillin selection plates containing 50 $\mu \mathrm{g} / \mathrm{mL}$ ampicillin and incubated at $37^{\circ} \mathrm{C}$ for 16 h. The colonies were counted and the titer (colony forming units, cfu/mL) was calculated according to the equation as follows: Titer $(\mathrm{cfu} / \mathrm{mL})=[($ number of colonies $) \times($ dilution factor $) \times(1000 \mu \mathrm{L} / \mathrm{mL})] /($ volume of phage plated in $\mu \mathrm{L})$.

To assess the insert size and transformation efficiency, an aliquot of the infected bacteria was plated onto an LB-ampicillin plate. After incubation at $37^{\circ} \mathrm{C}$ for $16 \mathrm{~h}$, individual colonies were inoculated into $5 \mathrm{~mL}$ of LB broth containing $250 \mu \mathrm{g}$ of ampicillin and cultured at $37^{\circ} \mathrm{C}$ for $16 \mathrm{~h}$ with shaking. The cosmids was extracted from $1.0 \mathrm{~mL}$ of the culture using the CTAB method (Sun and Zhang, 2009), resolved in $0.1 \mathrm{~mL}$ TE $(1 \times \mathrm{TE}$ contains $10 \mathrm{mmol} / \mathrm{L}$ Tris- $\mathrm{HCl}(\mathrm{pH} 8.0)$ and 1 $\mathrm{mmol} / \mathrm{L}$ EDTA-Na2), and analyzed with a 0.7 $\%$ agarose gel.

For average insert size investigation, 50 clones were randomly chosen; cosmid DNA prepared from each clone was digested with NotI (Takara, Japan) and EcoRI (Takara, Japan) and DNA fragments were checked by gel electrophoresis. Bands were visualized under UV light after EB staining.

\section{Amplification and storage}

Amplification of the packaged cosmids and storage in sterile glycerol were performed as recommended by the manufacturer.

\section{Library characterization}

To test stability of the library, one aliquot amplified cosmid library was taken and serial dilutions were performed. 30 colonies were randomly picked out and transferred into $5 \mathrm{ml}$ of LB medium separately and cultured for $14 \mathrm{~h}$. $0.8 \mathrm{ml}$ from each culture was dropped into a new tube and added sterile glycerol to a final concentration of $15 \%$ and stored at $-70{ }^{\circ} \mathrm{C}$ for 1 $\mathrm{d}$. The tubes were thawed and then $50 \mu \mathrm{L}$ was taken out from each culture, inoculated into another fresh $5 \mathrm{ml}$ of LB medium and cultured for $16 \mathrm{~h}$. Each clone was cultured in this way successively for 3 times. The cosmids was extracted from $1.0 \mathrm{~mL}$ of the culture using the CTAB method as described above and analyzed with a $0.7 \%$ agarose gel.

\section{Results \\ Preparation of genomic DNA and partial digestion conditions}

A relatively high amount of high molecular weight genomic DNA was isolated from mycelia produced from conidia of $C$. horii and $1.0 \mathrm{mg}$ genomic DNA was obtained. Analysis of pulse field gel electrophoresis showed that the majority of DNA fragments ranging between 145 and $250 \mathrm{~kb}$ were yielded (Fig 1), which was suitable for the requirement for construction of the library (about five times insert DNA size). The partial digestion conditions with Sau 3AI that yielded the majority of DNA fragments in the 30-42 kb range were established when $10 \mu \mathrm{g}$ genomic DNA was digested with $0.5 \mu 1$ Sau 3A I (0.2 U/ $\mu 1$ Sau 3A I) for $5 \mathrm{~min}$ and this conditions were used to digest a large amount of genomic DNA (100 $\mu \mathrm{g})$.

\section{Quality of the packaged cosmids}

After the digested DNA fragments were ligated, packaged plated with the Escherichia coli strains XL1-Blue MR, the colonies were counted and the titer was calculated. The result for titering cosmid library showed that the titer of packaged cosmids was $9.6 \times 10^{3} \mathrm{cfu} / \mathrm{mL}$ (Fig 2), and the total number of clones contained in the $C$. horii library was 47800 .

To check for the presence of the inserts, 50 colonies of XL1-Blue MR were randomly selected from LB-ampicillin plates. The cosmids were isolated, and then subjected to electrophoresis on a $0.7 \%$ agarose gel. Although the exact sizes of cosmids harboring the inserts were not measured by the agarose gel, the cosmids were detected in 20 clones, as shown in Fig 3. The remaining 30 clones examined 


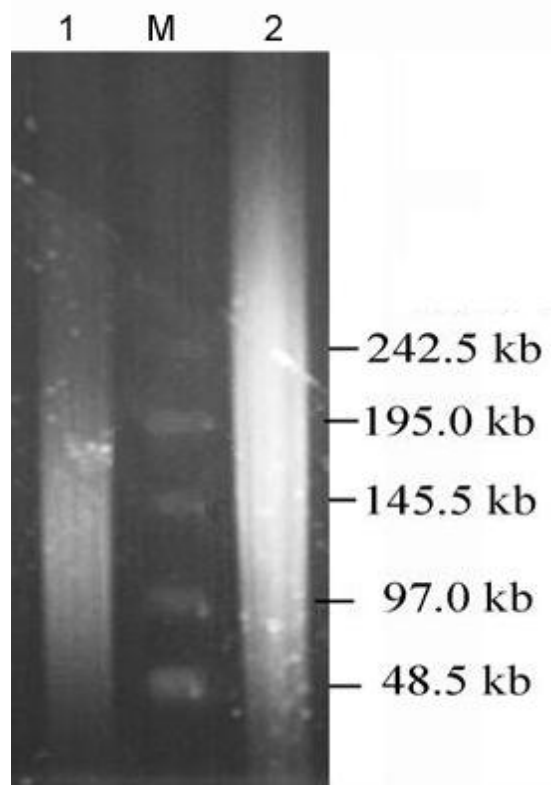

Fig. 1 - Pulsed-field gel electrophoresis (PFGE) pattern of genomic DNA from Colletotrichum horii performed at $148 \mathrm{C}$ in a $0.5 \%$ agarose gel. Lane 1. Purified genomic DNA. Lane 2. Purified genomic DNA by picking out with a capillary. Lane M, lambda ladder PFG marker (New England Biolabs, USA)

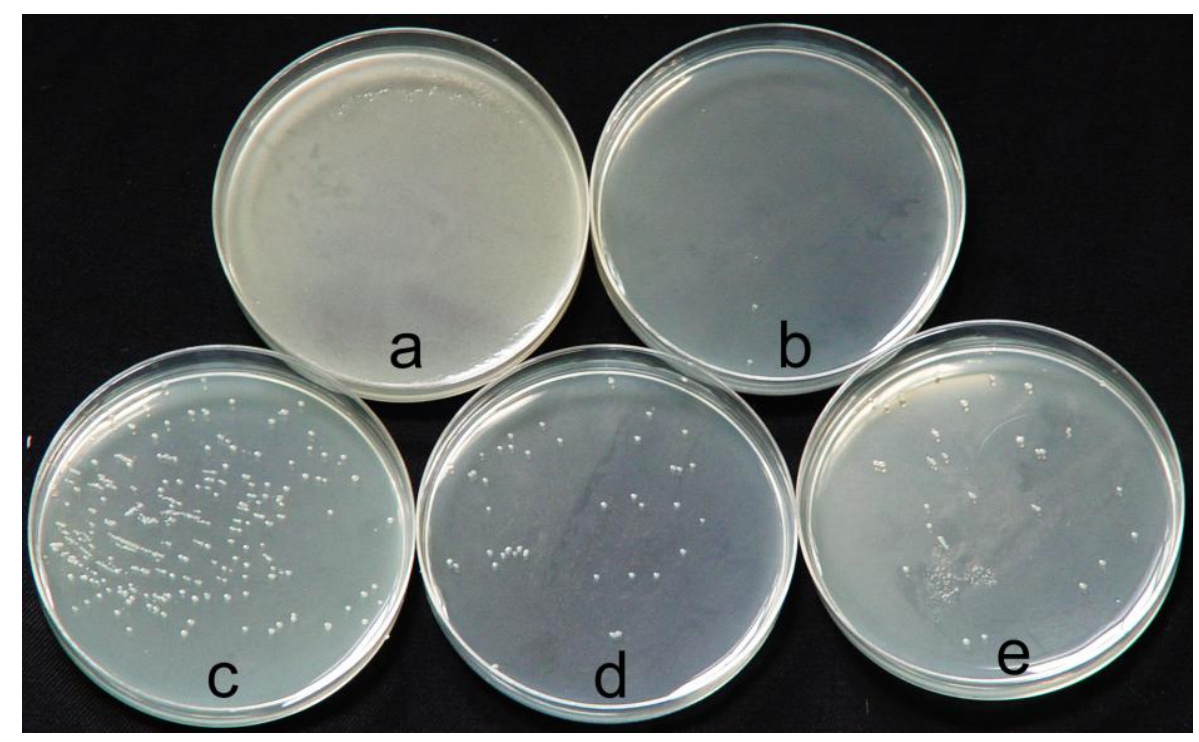

Fig. 2 - The colonies of bacterium strain XL1-Blue MR containing the packaged cosmids on LBampicillin selection plates with a serial dilution. (a) Positive control (VCS 257strain with Lamda DNA); (b) Negative control (no DNA); (c) A plate with a 1: 10 dilution. d. A plate with a 1: 50 dilution; (d) A plate with 1: 100 dilution.

were also of the same size (data not shown). The result shows the presence of inserts of about $40.5 \mathrm{~kb}$ ligated in the $7.9 \mathrm{~kb}$ of cosmid vectors and clones lacking inserts were not detected.

The cosmid DNA of 50 clones were digested by Not I and analysis of gel electrophoresis showed the insert size of 50 randomly picked clones ranged between 30 and $42 \mathrm{~kb}$ with an average of $34.8 \mathrm{~kb}$. The products of digested cosmids were detected in 16 clones, as showing Fig 4.

Similarly, the cosmid DNA of 50 clones was digested by EcoRI and analysis of 


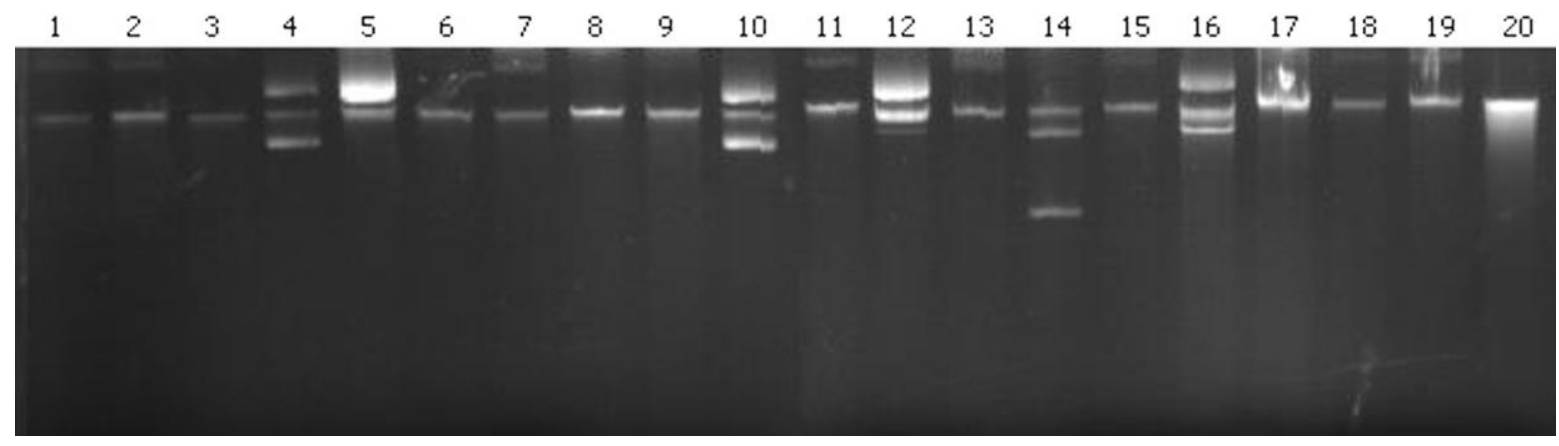

Fig. 3 - Insert check for the packaged cosmids. Lanes 1-20, cosmids purified from the infected XL1-Blue MR colonies. Cosmids were separated on a $0.7 \%$ agarose gel

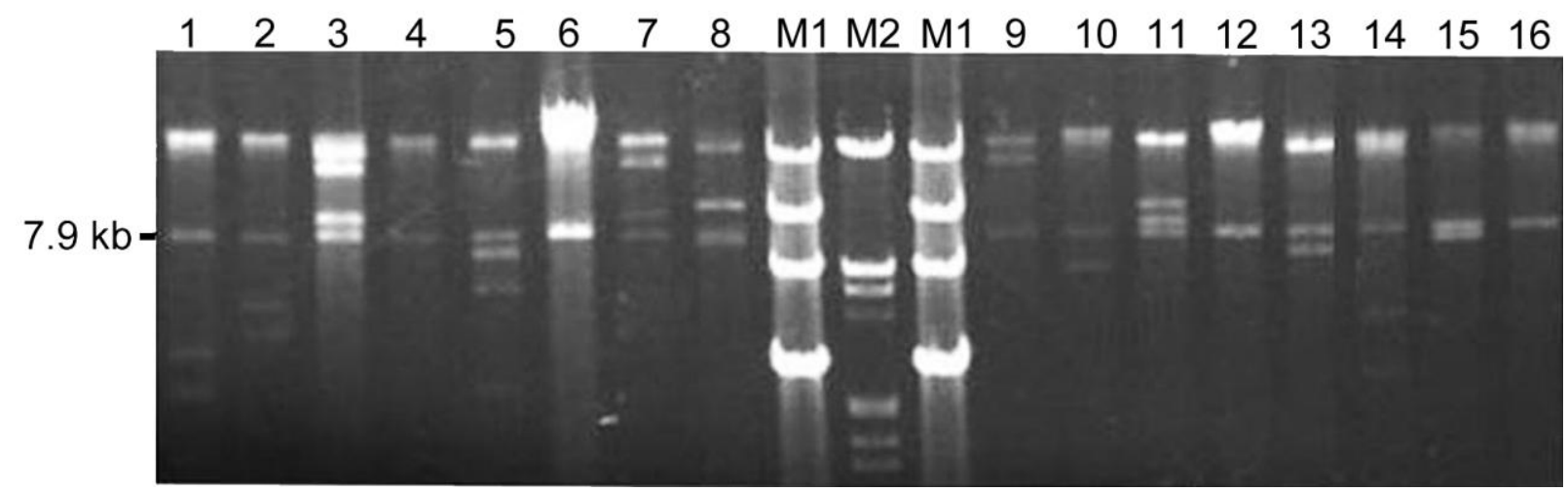

Fig. 4 - Insert check for the packaged cosmids with a NotI digestion. Lanes 1-16, cosmids purified from the infected XL1-Blue MR colonies. (M1) DNA size Marker(15; 8; 5 and $2.5 \mathrm{~kb}$, Takara, Japan); (M2) Lamda DNA / EcoRI \& HindIII (21.2, 5.1, 4.2, 3.5, 2.0, 1.6 and $1.4 \mathrm{~kb}$, MBI, Ferments)

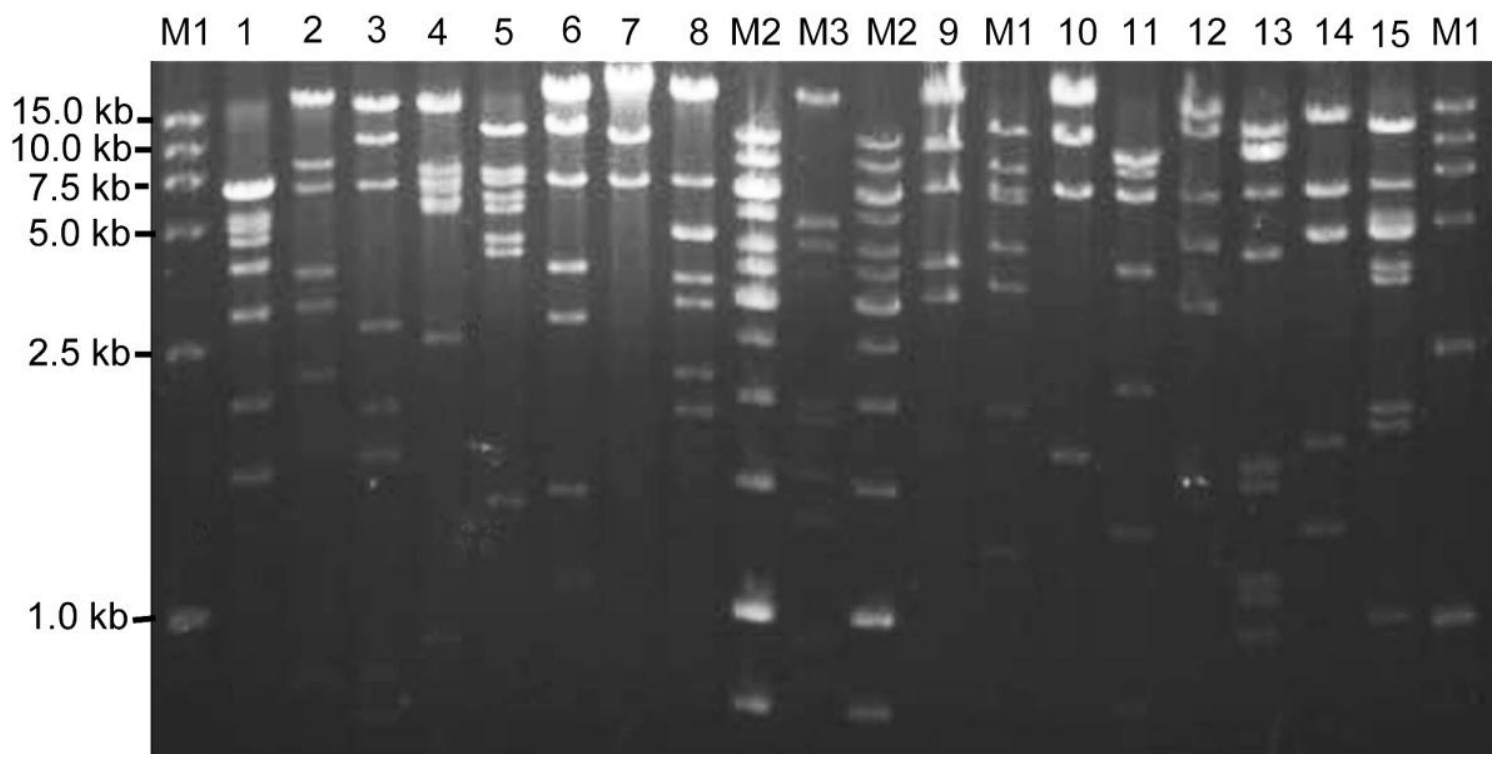

Fig. 5 - Insert check for the packaged cosmids with a EcoRI digestion. Lanes 1-15, cosmids purified from the infected XL1-Blue MR colonies. (M1) DNA size Marker ( Takara, Japan); (M2) DNA size Marker (10.0, 8.0, 6.0, 5.0, 4.0, 3.0, 2.0, 1.5, 1.0, .07, 0.5 and 0.3kb; Axygen, USA); (M3) lamda DNA/EcoRI \& HindIII (21.2, 5.1, 4.2, 3.5, 2.0, 1.6 and $1.4 \mathrm{~kb}$, MBI, Ferments 
Table 1 The relationship of average inserts size and necessary number of colonies

\begin{tabular}{llll}
\hline Genome size(bp) & $\begin{array}{l}\text { necessary number of } \\
\text { colonies(N) }\end{array}$ & Average insert size(bp) & $\boldsymbol{P}^{*}$ \\
\hline $5 \times 10^{7}$ & 6614 & $34.8 \times 10^{3}$ & 0.99 \\
$5 \times 10^{7}$ & 6871 & $33.5 \times 10^{3}$ & 0.99
\end{tabular}

$* P$ is the probability to find any given DNA sequence and was calculated by using an equation from Clarke $\&$ Carbon (1976); $\mathrm{N}=\ln (1-\mathrm{P}) / \mathrm{ln}(1-\mathrm{f})$, where $f$ is the fractional proportion of the genome in a single recombinant: $\mathrm{f}=$ average insert size (bp)/genome size (bp).

gel electrophoresis indicated that the insert size of 50 randomly picked clones ranged between $24-42 \mathrm{~kb}$ with an average of $33.5 \mathrm{~kb}$ (Fig 5).

\section{Characterization of the library}

The exact genome size of $C$. horii is unknown so far but the genome DNA content of $C$. graminicola had been shown to be 4.8$5.0 \times 10^{7}$ bp (Randhir \& Hanau, 1997). Therefore, the genome size of $C$. horii can be estimated within $5.0 \times 10^{7} \mathrm{bp}$. An equation from Clarke \& Carbon (1976) was used to calculate necessary number of colonies or the number of primary recombinants for the desired probability to find any given DNA sequence represented in the library (Table 1). Based on the number of primary recombinants (number of clones), the genome coverage of this library was approximately 6.96 genome equivalents or 7.22 .

The packaged cosmids were amplified in XL1-Blue MR host cells as recommended by the manufacturer and the colonies were counted and the titer $(\mathrm{cfu} / \mathrm{mL})$ was calculated as described above. The result of cosmid library amplification showed that the titer of packaged cosmids was $4.6 \times 10^{8} \mathrm{cfu} / \mathrm{mL}$. After amplifying cosmid library, the cell suspension with $15 \%$ glycerol and $100 \mu \mathrm{g} / \mathrm{ml}$ ampicillin was store in $1.5 \mathrm{~mL}$ microfuge tubes at $-80{ }^{\circ} \mathrm{C}$.

After the freeze/thaw cycle for three times, the result for titering cosmid library showed that the titer of packaged the titer of packaged cosmids was $4.0 \times 10^{8} \mathrm{cfu} / \mathrm{mL}$.

\section{Discussion}

Species of Colletotrichum use diverse strategies for invading host tissue, ranging from intracellular hemibiotrophy to subcuticular intramural necrotrophy. In addition, these pathogens develop a series of specialized infection structures, including germ tubes, appressoria, intracellular hyphae, and secondary necrotrophic hyphae. Colletotrichum species provide excellent models for studying the molecular basis of infection structure differentiation and fungal-plant interactions (Perfec et al.1999). Cytological studies clearly show that the infection process and intracellular infection structures of $C$. horii are different from that of $C$. gloeosporioides (Sutton 1992) and similar to hemibiotrophic species of Colletotrichum (Perfec et al.1999), but more closely related to that of $C$. lindemuthianum on bean (O'Connel et al. 1985). How-ever, the molecular mechanisms of interaction between pathogen and host are not well understood. The genomic libraries were used wisely as an important means for the target gene cloning in Colletotrichum (Huser et al. 2009, Kim et al. 2000) while construction of the genomic library of $C$. horii provides a important approaches for isolation of genes related to molecular events.

In construction of the genomic library, it is important to prepare larger genomic DNA. By obtaining mycelia producing from conidial germination and removing smaller DNA fragments with a capillary, we established successfully a method to isolate DNA of high molecular weight with sufficient purity and to construct a cosmid library. To our knowledge, this is the first cosmid library constructed for a persimmon anthracnose pathogen. The DNA was easily digestible and partial digestion conditions with Sau 3AI that yielded the majority of DNA fragments in the $30-42 \mathrm{~kb}$ range were established as well. The library of $C$. horii reported here was shown to be representative for the entire genome with a calculated $99 \%$ probability to find any given 
DNA sequence. Because the amount of insert DNA included in the ligation reaction is proportional to the eventual number of clones in the library, after amplifying cosmid library, our library is to obtain more concentrated insert DNA and to construct a library having many more clones. Although southern blot analysis data is not showed for determining the kind of insert DNA, these will be indicated detailly in another paper, while in this study, we put more emphasis on the construction and characterization of a genomic library of $C$. horii. Much work associated with cloning of pathogenesis-related genes is being conducted using this library, which will be a valuable source for the isolation of genes from the fungal $C$. horii .

\section{References}

Clarke L, Carbon J. 1976 - A colony bank containing synthetic ColE1 hybrids representative of the entire E. coli genome Cell 9, 91-99.

Huser A, Takahara H, Schmalenbach W, O'Connell R. 2009 - Discovery of pathogenicity genes in the crucifer anthracnose fungus Colletotrichum higginsian$u m$, Using random insertional mutagenesis, Molecular Plant-Microbe Interactions 22(2), 143-156.

Hyde K.D, Cai L, Cannon P.F, Crouch J.A, Crous P.W, Damm U, Goodwin P.H, Chen H, Johnston P.R, Jones E.B.G, Liu Z.Y, McKenzie E.H.C, Moriwaki J, Noireung P,Pennycook S.R, Pfenning L.H, Prihastuti H, Sato T, Shivas R.G, TanY.P, Taylor P.W.J, Weir B.S, Yang Y.L, Zhang J.Z. 2009 - Colletotrichum names in current use. Fungal Diversity 39, 147-182.

Kim Y.K, Liu Z.M, Li D, Kolattukudy, P.E. 2000 - Two novel genes induced by hard-surface contact of Colletotrichum gloeosporioides conidia. Journal of Bacteriology 182(17), 4688-4695. Mycology.(in press)

O'Connell R.J, Bailey J.A, Richmond D.V. 1985 - Cytology and physiology of infection of Phaseolus vulgaris by Colletotrichum lindemuthianum. Physiology and Plant Pathology 27, 75-98.
Perfect S.E, Hughes H.B, O'Connell R.J, Green J.R. 1999 - Colletotrichum: A model genus for studies on pathology and fungal-plant interactions. Fungal Genetics and Biology 27, 186-198.

Randhir R.J, Hanau R.M. 1997 - Size and complexity of the nuclear genome of Colletotrichum graminicola. Applied and Environmental Microbiology 63, 40014004.

Sun H, Zhang J.Z. 2009 - Colletotrichum destructivum from cowpea infecting Arabidopsis thaliana and its identity to C. higginsianum. European Journal of Plant Pathology $125,459-469$.

Sun H, T. Xu, Zhang J.Z. 2008 - Genome library construction of anthracnose pathogen on persimmon and screening of pathogenesis related mutants for analysis. $\mathrm{PhD}$ thesis, Zhejiang University, Zhejiang, China 151 (in Chinese).

Sutton B.C. 1992 - The genus Glomerella and its Anamorph Colletotrichum. In: Bailey, J. A., Jeger, M. J., eds., Colletotrichum: Biology, Pathology and Control. Pp. C. A. B. International, Wallingford, pp., 1 27.

Weir B.S, Johnston P.R. 2010 Characterisation and neotypification of Gloeosporium kaki Hori as Colletotri-chum horii nom. nov. Mycotaxon, 111:209-219.

Xie L, Zhang J.Z, Cai L, Hyde K, D. 2010 The biology of Colletotrichum horii, the causal agent of Persimmon anthracnose. Mycology 1: 242-253.

Zhang J.Z, Hu D.W, Xu T. 2003 - Studies on cytology of the infection of persimmon by Colletotrichum gloeosporioides. Mycosystema 22 (4), 645-652 (in Chinese).

Zhang J.Z, Hu D.W, Xu T. 2005a Ultrastructure of infection of persimmon petiole by Collectotrichum gloeosporioides. Acta Phytopathologica Sinica 35(5), 434-441 (in Chinese).

Zhang J.Z, $\mathrm{Xu}$ T, He L.P. 2005b Anthracnose pathogen on Diospyros kaki cv. Wuheshi and its nuclear behavior in process of appressorium formation. Mycosystema 24 (3), 446-456 (in Chinese).

Zhang J.Z. 2008 - Anthracnose of Persimmon Caused by Colletotrichum gloeospori- 
oides in China. Asian and Australasian Journal of Plant Science and Biotechnology 2(2), 50-54. 